\title{
OBRZĘDY SAKRAMENTU MAŁŻEŃSTWA WEDŁUG TRADYCJI KOŚCIOŁA BIZANTYŃSKIEGO
}

\author{
A. OBIRZED ZAHECZYN
}

Po Boskiej Liturgil, kiedy kapłan stoj w sanktuarium, przed bramą prowadząca z przedsionka do świł̨tyni ustawiają się pragnący zawrzé́ zwiłzek małżeński: mężczyza z prawej, a kobieta z lewej strony. Na ołtarzu leźa obok sieble dwie obrączki, złota 1 srebrna, srebrna po prawej, a złota po lewej stronie. Kapłan błogosławi trzykrotnie głowy zaręczających się, wręcza im zapalone świece 1 wprowadziwszy do świątyni okadza wształcie krzyza.

Diakon: Błogosław, Panie.

Kapłan: Błogosławiony Bóg nasz, wazdym czasie, teraz 1 zawsze 1 na wiek1 wieków.

Chór: Amen.

Diakon: Módlmy się wokoju do Pana.

Chór: Kyrie eleison.

Diakon: 0 pokój z wysokości 1 o lch zbawienie, módlmy się do Pana. Chór: Kyrie eleison.

Diakon: 0 pokój dla całego świata, pomyślność swiętych bożych Kościołów, 1 zjednoczente wszystkich, módlmy się do Pana.

Chór: Kyrie eleison.

Diakon: Za ten święty dom Bozy 1 za tych, którzy z wiarą, poboznością 1 bojaźnią boża wchodzą do niego, módlmy się do Pana.

Chór: Kyrie eleison.

Diakon: Za arcybiskupa naszego $\mathrm{N}^{3}{ }^{3}$, za czcigodnych kapłanów, za diakonów Chrystusie, za cały stan duchowny 1 lud, módlmy się do Pana.

Chór: Kyrie eleison.

Diakon: Za sługe bożego N. 1 za słuźebnice boźa N., którzy teraz się zaręczają oraz o ich zbawiente, módlmy się do Pana.

1 Nazwa grecka $\mu \nu \eta \sigma \tau \varepsilon l \alpha / \tau \alpha \mu \nu \eta \sigma \tau \sigma \alpha$ / oznacza "dodawać cos sob1e" / na przykład męża/, "swatać się". W Euchologionach konstantynopolitanskich nie wystęuje wielka ektenia. Tekst: J.Goar, Euchologion sive rituale Graecorum, Graz 1960, 310-312. Nerylikacj1 tłumaczenia dokonał ks.S.Longosz.

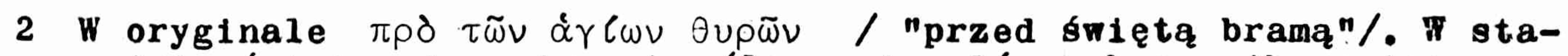
rożytności terminem tym określano nie główną bramę lkonostasu, ale bramę prowadzącą z przedsionka do świątyni.

3 Starozytna praktyka wymagała, zeby kapłan wspominał tylko swego 
Chór: Kyrie eleison.

Diakon: Aby otrzymali potomstwo jako przedłużenie rodu 1 wszystko potrzebne do zbawienia, módlmy się do Pana.

Chór: Kyrle eleison.

Diakon: Aby lm zostala udzielona zgodna i doskonała miłośc oraz -pomoc, módlmy się do Pana.

Chós: Kyrie eleison.

Diakon: Aby zostali zachowani w jednomyślności 1 niezachwianej wierze, módlny się do Pana.

Chór: Kyrioleison.

Dlakon: Aby otrzymali blogosiawieństwo w zgodzle 1 niezachwianej wierze, módlmy się do Pana.

Chór: Kyrto eleison.

Diakon: Aby byl1 zachowani wieskalanym zyciu 1 obcowaniu, módlmy się do Pana.

Chór: Kyrie eleison.

Diakon: Aby Pan Bóg nasz dał im godne małżéstwo 1 łoże nieskalane, módimy się do Pana.

Chór: Kyrie eleison.

Diakon: Abyśmy zostali wybawieni od wszelkiego utrapienia, gniewu 1 niedostatku, módlmy się do Pana.

Chór: Kyrie eleison.

D1akon: Wspomniawszy Najśw1ętszą, Przeczystą, Błogosławioną i pełną chwały Pania nasza Bogurodzice 1 zawsze Dziewicę Martę wraz ze wszystkimi świętymi, polecajmy samych siebie, innych ludzi $i$ całe źycie nasze Chrystusowi Bogu.

Chór: Tobie, o Panie.

Kapłan: Tobie bowiem należy się wszelka chwała, cześć $i$ uwielbienie, ojcu i Synowi i Swietemu Duchowi teraz 1 zawsze i na wieki wieków.

Chór: Amen.

Kapłan mówi następnie podniesionym głosem modlitwę:

Boże wieczny. Który rzeczy rozdzielone łaczysz w jedno i nakładasz im nierozerwalny zwiłzek miłości, Który pobłogosławiłeś Izaaka i llebekę oraz uczyniłeś ich dziedzicami Twojej obietnicy, sam również pobłogosław i te sług1

biskupa, biskup patriarchę, a głowa Kościoła wszystkich innych patriarchów. 
twoje N. I N., prowadząc ich w pełnieniu wszelkich dobrych czynów.

Ponieważ jesteś Bogiem miłosiernym i miłującym ludzi, 1 tobie chwałe oddajeny, ojcu i Synowi 1 Swietemu Duchowi, teraz 1 zawsze 1 na wieki wieków.

Chór: Amen.

Kapłan: Pokóf wszystkim.

Chór: I z duchem troim.

Diakon: Pochylcie głowy wasze przed Panem.

Chór: Przed Tobą, Panie.

Kapłan: Panie Boże nasz, Który spośród narodów poślubiłeś Kościół, czysta oblubientce, pobłogosław 1 te zareczyny oraz zjednocz i zachowaj te sługi swoje pokoju 1 jednomyślności. Tobie bowiem przynalezy wszelka chmała, cześć 1 uwielbienie, ofcu 1 Synowi 1 Swietemu Duchowi, teraz 1 zawgze 1 na wie$k 1$ wiek $6 w^{4}$.

Chór: Amen.

Kapłan wziąwszy następnie obrączki ${ }^{5}$ podaje najpierw męzozyźnie złotą, a potem kobiecie srebrną 1 mówi do mężczyzny:

Zaręczany jest sługa boży $N_{\text {, }}$ e słuzebnica bożą No, T imie ojca 1 Syna 1 Swiętego Ducha, teraz 1 zawsze 1 na wieki wieków Amen.

Następnie mowi do kobiety:

Zaręczana jest słuźebntca boża N. ze sługą bożym N., Timię ojca i Syna 1 Swiętego Ducha teraz 1 zawszo 1 na wieki wioków. Amen.

Kapłan mówi to trzykrotnie czyniąc znak krzyża obrączkami nad ich głowami, a następie nakłada je na ich prawice. Swladek natomiast zamienia obrazczk1 zareczonym.

4 W tej modlitwio zaręczyn kapłan mówi, że Chrystus zaślubił/

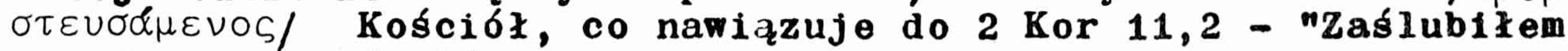
was jednemu mężowi".

5 Obrączek zareczynowych nie uzywano jeszcze w VII wieku, lub byé moze ich wymiana miała miejsce poza ceremonia kościelna. 
Kapłan: Módlmy się do Pana.

Panie Boże nasz, który towarzyszyłoś słudze ${ }^{6}$ patriarchy Abrahama Mezopotamil, posłanemu w celu znalezienia zony dla jego Pana Izaaka 1 poprzez posługe noszenia wody wskazałeś mu, żeby się zaręczył z Rebeką/Rdz 41,12/, sam pobłogosław zareczyny Twolch sług N. 1 N., umocnij wypowiedziane przez nich słowo 1 umocnij lch w twojej swiętej jedności. Ty bowiem na początku stworzyłeś męzczyznę 1 kobiete 1 z Twojej woll zona łączy się z mężem jako pomoc 1 ku przedłużeniu rodzaju ludzkiego. Sam przeto, Panie Boże nasz, który dałeś prawde Tremu dziedzictwu i Twoja obietnice sługom Twoim, ojcom naszym, wybranym Twoim z pokolenia na pokolente, wejrzyj na sługe Twego $N$. 1 na słuzebnice Twoja N. 1 umocnij ich zareczyny wierze, jednomyślności, pramdzie i miłości. Ty bowiem Panie, nakazałeś dać pierścień 1 umacniać pierścieniem wszystkie umowy ${ }^{7}$. Poprzez pierścień dana została Józefowi władza - Egipcie/ndz 41,42/, poprzez pierścién uczczony został Daniel w kraju babilońskim/Dn 6,17/, poprzez pierácień objawiła się prawda Tamary /Rdz 38,25/, poprzez plerścień ojciec nasz niebieski okazał szczodrobliwośc swemu Synowi. Powiedzial bowlem: Włóżcie pierścień na jego prawicę, zabijcie cielca tucznego 1 jedząc radujcie się/Lk 15,22/. Ta sama prawica Twoja, Panie, przeprowadziła Mojzesza w Morzu Czerwonym /Wj 14,31/, a poprzez prawdziwe Twoje słowo niebo zostało uczynione 1 ziemia załozona. Takze prawica sług twoich błogosławiona jest przez Twoje słowo potęźne 1 ręke twoja $z$ wysoka. Sam przeto, Panie, pobłogosław to założente obrączek błogosławieństwem z niebios,

6 oryginale $\pi \alpha \tau_{\zeta} / \mathrm{scs}$. otrok/, co odpowiada znaczentu "chłopiec na posyłki".

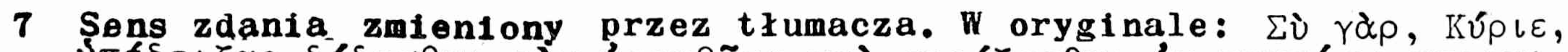

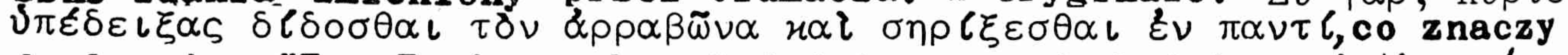
dosłownie: "Ty, Panie, nakazałes dac posag/rękojmię majątkowa/ 1 nim wszystko potwierdzaćn. Przekład słowiańsk1/Ty bo Gospodi pokazal jesi datisja obruðeniju 1 utverždatisja vo vsem/ stosuje tu zmiękczenie: "Ty bowiem, Panie, kazałeś dać zaręczyny 1 tym wszystko umacniaćn. Użycie w tekście greckim słowa \& $\rho \rho \alpha \beta \tilde{v} \nu \alpha$ nawiazuje do starożtnych zwyczajów obowiazkowego dania posagu 
a anioł Twój niech kroczy przed nimi przez wszystkie dni ich życia.

Poniewaz Ty błogosławisz 1 uswięcasz Wszystko, Toble chwałe oddajemy, ojcu i Synowi i Swiętemu Duchowi, teraz 1 zawsze 1 na wiek 1 wiekow 8 .

Chór: Amen.

tłum。Ks. Henryk Paprock1 - Warszawa

narzeczonej przez jej rodziców.

8. Ostatnia modlitwa zaręczyn nie występuje w Codex Barberin1 gr. 336 . W tekście tej modiitwy rdzeń $\alpha \rho \rho \alpha \beta \omega ́$ wystepuje cztery razy. Słowo to ma charakter czysto jurydyczny lub nawet handlowy /przekład staro-corkiewno-słowiański stosuje tu zmiękczenie obručenije - obručit1/. W Codex Barberini gr. 336 zaręczyny składają się tylko z dwóch pierwszych modlitw. 


\section{B. OBRZĘD KOLONOHANIA /ślubnego/1}

Jeżel1 zaręczeni chcaz zaraz otrzymać koronowanie/ślub/, to wchodzą do świątyni ${ }^{2}$ z zapal onymi świecami, poprzedzani przez kapłana z kadzielnica. Kapłan śpiewa Psalm 127, a lud na każdy werset odpowiada: "Chwała Tobie, Boźe nasz, chwała Tobie".

Kapłan: Błogosławieni są wszyscy, którzy boją się Pana

Lud: $\quad$ Chwała Tobie, Boże nasz, chwała Tobie.

Kapłan: Którzy chodzą Jego drogami.

Lud: Chwała Tobie, Boże nasz, chwała Tobie.

Kapłan: Owoce pracy rąk swoich pużywać będziesz.

Lud: $\quad$ Chwała Tobie, Boże nasz, chwała Tobie.

Kapłan: Błogosławiony jesteś i dobrze ci będzie.

Lud: Chwała Tobie, Boźe nasz, chwała Tobie.

Kapłan: Zona twoja jak winorośl płodna w zaciszu twego domostwa,

Lud: $\quad$ Chwała Tobie, Boże nasz, chwała Tobie.

Kapłan: Synowie twoi jak gałazki oliwne dokoła twego stołu.

Lud: $\quad$ Chwała Tobie, Boże nasz, chwała Tobie.

Kapian: Tak oto błogosławiony będzie człowiek, który boi się Pana.

Lud: Chwała Tobie, 3oze nasz, chwała Tobie.

Kapłan: Nioch ci błogosławi Pan ze Syjonu, abyś oglazdał pomyślność Jeruzalem po wszystkie dni Twego żywota.

Lud: Chwała Tobie, Boże nasz, chwała Tobie.

Kapłan: Abyś oglądał dzieci troich synów. Pokóf nad Izraelem.

Lud: Chwała Tobie, Boże nasz, chwała Tobie.

Następnie kapłan wygłasza pouczenie mówiąc czym jest małżeństwo i jak w małżeństwie należy poboźnie i czcigodnie żyć. Po skończeniu zaś pouczenia następują pytania i przysięga 3:

1 W Codex Barberini gr. 336 obrzęd ten nosi nazwę rópol, natomiast

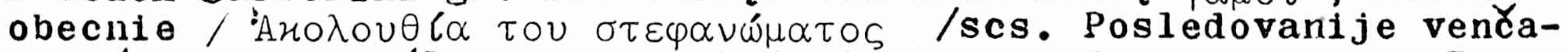
nija/, co podkreśla moment założenia koron. Tekst: J.Goar, Euchologion sive rituale Graecorum, Graz 1960, 314-320. Weryfikacji tłumaczonia dokonał ks.S.Longosz.

2 W Codex Barberini gr. 336 nie ma uroczystego wejścia nowożeńców do świątyni.

3 W Codex Barberini gr. 336 nie ma pytań stawianych przez kapxana, które występuja wościołach z tradycją liturgiczna uzaleźnioną od rosyjskiej. Pytania te do dzisiaj nie występują w tradycji 
Kapłan:

N., czy masz dobraz i nie przymuszonaz wole oraz mocne postanowienie pojąć sobie za żonę tę oto N., którą tu

- przy soble widzisz?

Oblubieniec: Mam, czcigodny ofcze.

Kapłan: Czy nie obiecałeś małżeństwa innej kobiecie?

Oblubieniec: Nie obiecałem, czcigodny ojcze.

Z kolei kapłan zadaje pytania oblubienicy:

Kapłan: $\quad$ N., czy masz dobrą i nie przymuszona wole oraz mocne postanowienie pojáć sobie za męza tego oto N., którego tu przy sobie widzisz?

Oblubienica: Mam, czcigodny ojcze.

Kapłan: Czy nie obiecałaś małżeństwa innemu mężczyźnie?

Oblubienica: Nie obiecałam, czcigodny ojcze.

Diakon: Błogosław, Panie.

Kapłan: Błogosławione Królestwo ojca i Syna 1 Św1ętego Ducna, teraz i zawsze i na wieki wieków ${ }^{4}$.

Diakon: Módlmy się pokoju do Pana.

Chór: Kyrie eleison.

Diakon: $\quad 0$ pokój $z$ wysokości i o lch zbawienie módlmy się do Pana.

Chór: Kyrie eleison.

Diakon: $\quad 0$ pokój dla całego świata, pomyślność świętych bożych Kościołów i o zjeảnoczenie wszystkich, módlmy się do Pana.

Chór: Kyrie eleison.

Diakon: Za ten święty dom Boży 1 za tych, którzy z wiarą, poboźnościa 1 bojaźniaz bożą wchodzza do niego. módlmy - sie do Pana.

greckiej. W "Trebniku" Piotra Mohyły /Kijev 1646, 416/ została poza tym wprowadzona przysięga małzeńska, co jest wyraźnym wpływem łacińskim.

4 Jest to poczatkowa ak lamacja Liturg11 eucharystycznej. Rozpoczynają się nią obrzędy chrztu 1 małzeństwa, co świadczy, że rożtności sakramenty te były celebrowane połączeniu z Eucharystia. 
Chór: Kyrie eleison.

niakon: Za arcybiskupa naszego N, za czcigodnych kạłanów, za diakonów w Chrystusie, za cały stan duchowny i lud, módlmy się do Pana.

Chór: Kyrie eleison.

Diakon: Za sługi boże N, i N, którzy teraz wstępują wedność zwiłzku małzeńskiego 1 o ich zbawiente, módlmy się do Pana.

Chór: Kyrie eleison.

Diakon: Aby ten zwiazek został pobłogosławiony jak $6 w$ w Kanie Galilejskiej, módlmy się do Pana.

Chór: Kyrie eleison.

Diakon: Aby otrzymali dar czystości 1 owoc łona ku pozytkowi, módlmy się do Pana.

Chór: Kyrie eleison.

Diakon: Aby radowall się widokiem synów 1 córek, módlmy sie do Pana.

Chór: Kyrie eleison.

Diakon: Aby otrzymali dar potomstwa i nieśralany sposób życia, módlmy siq do Pana.

Chór: Kyrie eleison.

Diakon: Abyśny wraz z nimi otrzymali wszystko, o co prosimy do zbawienia, módlmy się do Pana.

Chór: Kyrie eleison.

Diakon: Abyśmy zostali wraz z nimi wybawieni od wszelkiego utrapionia, gniewu $i$ niedostatku, módlmy się do Pana.

Chór: Kyrie eleison.

D1akon: Wspomóż, zbaw, zmiłuj się i zachowaj nas, Boże, swoją zaskiz.

Chór: Kyrie eleison.

Diakon: Wspomniawszy Najświętszą, Przeczystž, Błogosławioną

1 pełna chmały Pania nasza Bogurodzice i zawsze Dziewicę Marie wraz ze wszystkimi świętymi, polecajmy samych siebie, innych ludzi i całe żvcie nasze Chrystusowi Bogu.

Chór: Tobie, o Panie.

Kapłan: Albowiem Tobie nalezy sie wszelka chwała, cześć i uwlelbienie, ojcu 1 Synowi $i$ Duchowi Swiętemu, teraz 1 zawsze 
1 na wiek1 wieków5

Chór: Amen.

Diakon: Módlmy się do Pana.

Chór: Kyrie eleison.

Kapłan: Boze Przeczysty 1 Stwórco wszelkiego stworzenia, któryśs zebro praojca Adama przemieniz z miłosci Twej ku ludziom w niewlastę 1 błogosławił im mówiąc: "Rośnijcie 1 mnózcie się oraz czyńcie soble ziemie poddaną", i zechciałes ich dwoje połaczyć przez małzeństwo jedno ciało. Dlatego to opuści człowlek ojca swego 1 matke 1 połaczy sie ze swoją zoną 1 będą dwoje jednym ciele" /lidz 2,18-24/, a "ḱtórych Bóg złaczył, człowlek niech nie rozłączan/Mt $19,6 /$. Ty otworzywszy łono Sary pobłogosławiłeś słudze swemu Abrahamow1 1 uczyniłeś go ojcem mnóstwa narodów/Rdz 18,10-18/: Ty dałeś Rebece Izaaka i pobłogosławiłes jej macierzyústwo /Rdz 24/; Ty połaczyłeś Jakuba z Rachelaz 1 wywiodłeś z nich dwunastu patriarchów /ildz 29-30/; Ty połączyłeś Józefa 1 Asenetę oraz dałeś $1 \mathrm{~m}$ jako owoc potomstwo, Efrema 1 Manassesa/ndz 41,45-52/; Ty przyjąwszy Zachariasza i Elzbiete wskazałes 1m, ze narodzi się Poprzednik/Lk 1,5-25/; Ty sprawiłes, ze z korzenia Jessego wyrosła w ciele Dzlewica /Iz 11,10/, a Niej Wcielony narodził się na zbawienie rodzaju ludzkiego, Który z niewypowiedzianego Twego daru 1 wielkiej dobroci przybył do Kany Galilejskiej, gdzie pobłogosławił małzeństwo udowadniając, ze Troją wola jest prawny zwiazzek małzeński i pochodzące z niego rodzenie potomstwa /J 2,1-11/. Sam, Pante Najświętszy, przyjmij modlitwy nas sług Twoich 1 jak tam/w Kanie/, tak 1 tutaj temu małżenstwu stań ntowidzialna Twojł obecnościa, pobłogosław temu małzeństwu 1 daj sługom Twoim N. 1 N. długie 1 spokojne zycie, czystość, wajemna miłość 1 zgodę małzeństwie, długowieczne potomstwo, błogosławieństwo w dzieciach 1 niewiędnący wientec chwały. Pozwól im oglazdać dziec1 swych dzlec1, zachowaj ich łoze od zasadzek oraz daj im z rosy niebieskiej 1 z bogactwa ziemi. Napełnif $1 \mathrm{ch}$ domy

5 W Codex Barberint gr. 336 występuje krótsza wersja tej ekteni1, 
pszenica, winiem, oliwa 1 wszelkimi dobrami, aby mogli tez słuźyć potrzebującym i dawać bliźnim wszystko, czego potrzebuja do zbawienta. Poniewaz jesteś Bogiem miłosierdzia, zmiłowania i miłości ku ludziom, oddajemy chwałe Toble z Przedwiecznym Twoim ojcem 1 Najświętszym, Dobrym 1 Źyciodajnym Twoim Duchem, teraz 1 zawsze 1 na wieki wieków ${ }^{6}$.

Chór: Amen.

Diakon: Módlmy się do Pana.

Chór: Kyrie eleison.

Kapłan: Błogosławiony jesteś, Panie Boże nasz, Kapłanie małzeństwa mistycznego i nieskalanego, Prawodarco cielesnego, Stróźu niezniszczalności 1 roztropny iządco spraw życiowych. Panie, który na początku stworzyłeś człowieka 1 uczyniłes go królem stworzeń oraz powiedzlałeś "Niedobrze byé człowiekori samemu na ziemi, uczyímy mu poisoc według niego", a wziąwszy jedno z jego zeber, stworzyłeś niewiastę, którą gdy ujrzał Adam, powiedział:"0to kość z kości moich i ciało z mego ciała, ona będzie nazwana żoną, gdyz sama z męża jest wzięta. Dlatego opuści człowiek ojca swego i matke 1 połączy się ze swoją żoną i będą dwoje w jednym ciele /idz 2,18-24/, a których Bóg złączył, człowiek niech nie rozłącza" /Mt 19,6/. I teraz Panie, Władco, Boze nasz, sam ześlij swoją łaskę niebieska na sługi Twoje N. 1 N., daj tej słuzebnicy, aby we wszystkim była poddana męźowi i temu słudze Twemu, aby był głowa żony 1 żeby żyli według Twojej woli. Pobłogosław im, Panie Boże nasz, jak pobłogosławiłeś Abrahamowi i Sarze. Pobłogosław im, Panie Boże nasz, jak pobłogosławiłeś Izaakowi 1 Rebece. Pobłogosław im, Panie Boze nasz, jak pobłogosławiłeś Jakubowi i wszystkim patriarchom. Pobłogosław im, Panie Boże nasz, jak pobłogosławiłeś Józelowi 1 Asenecie. Pobłogosław im, Panie Boże nasz, jak pobłogosławiłeś Mojzeszow1 1 Seforze. Pobłogosław im, Panie Boze nasz, jak pobłogosławiłés Joachimowi i Annie. Pobłogosław im, Panie Boże nasz, Jak pobłogosławiłeś Zachariaszowi 1 Elźbiecie. Za- 
chowaj ich, Panie Boze nasz, jak zachowałeś Noego w arce. Zachowaj Ich, Panie Boze nasz, jak zachowałeś Jonasza we mnętrzu wielkiej ryby. Zachowaj ich, Panie Boze nasz, Jak zachowałeś od ognia świętych trzech młodzieńców, zsyłając im rosez zieba. Niech zstąpi na nich ta radośc, jakiej doświadczyła święta Helena, gdy znalazła drogocenny krzyż. Pamiętaj o nich, Panie Boże nasz, jak pamiętałeś o Henochu, Semie i Eliaszu. Pamiętaj o nich, Panie Boże nasz, jak pamiętałeś o Twoich świętych czterdziestu męczennikach, zsyłając im z niebios korony. Pamiętaj również, Boże, o rodzicach, ktorzy ich wychowali, gdyz modlitwy rodzlców unacniaja fundamenty domów. Pamiętaj, Panie Boze nasz, o weselnych sługach Trolch tutaj zgromadzonych, którzy przyszli uczestniczyć tej radości. Pamiętaj, Panie Boze nasz,o słudze Troim N. 1 o służebnicy Twojej N. 1 pobłogosław im. Daj Im owoc łona, liczne potomstwo, zgodnośc dusz i c1ał, oraz mywyższ ich jak cedry libańskie, jak bujnie rosnąca latorośl. Daj im dobre urodzaje, aby obdarzeni dostatkiem obfitowali we wszelkie dobre 1 miłe Ci dzieła, aby oglądali synów swoich synow jak młode gałazki oliwne dookoła ich stołu, a podobając się Tobie, aby jaśnteli jak gwiazdy na niebie, Tobie, Panu naszym. Z Toba bowiem jest chwała, panowante, cześć $i$ uwielbienie oraz z Przedwiecznym Two1m 0jcem 1 Zyciodajnym Twoim Duchem, teraz 1 zawsze 1 na wieki wiekón ${ }^{7}$.

Chór : Amen.

Diakon: Módlmy się do Pana.

Chór: Kyrie eleison.

Kapłan: Swięty Boze, który z prochu uczyniłeś człowieka, a z jego żebra utworzyłeś niewiastę dołączając mu ja do pomocy, bo tak się spodobało Twojej wielkości, zeby człowiek nie by samotny na ziemi. Teraz Ty sam, Władco, wyciągnij swą rękę ze świętego przybytku Twego 1 połącz sługę Twego N. 1 słu-

7 Modlitwa ta nie występuje w Codex Barberini gr. 336, wystepuje natoniast w Codex Porfiril/X wiek/. 
żebnicą Twoją N., ponieważ przez Ciebie źona łączy się z męże. Połacz ich w jednomyślności, ukoronuj ich wedno ciało, daj im owoc łona $i$ pozytek z potomstwa. Twoje bowiem jest panowanie, Twoje królestwo, moc 1 chwała, ojca I Syna i Swlętego Ducha, teraz 1 zawsze $i$ na wieki wieków.

Chór: Amen.

Kapłan bierze korony 1 nakłada je najpierw oblubieńcowi mówiąc:

Koronowany jest sługa Boży N. dla służebnicy Bożej N., w imię ojca 1 Syna i Swiętego Ducha 8 .

Kapłan koronuje także oblubienicę mówiąc:

Koronowana jest służebnica Boża N. dla sługi Bożego N., w Imię Ojca 1 Syna i Swietego Ducha.

Następnie błogosławi ich trzykrotnie mówiąc za każdym razem:

Panie Boże nasz, ukoronuj lch chwała i dostojeństwem.

Diakon: Bądźmy uważni.

Lektor: Prokımen, ton 8: Włoźyłeś na 1ch głowy korony z drogich kamieni.

Werset: 0 zycie prosili Ciebie i dałeś im.

Werset: Albowiem dałeś im błogosławieństwo na zawsze, uweselasz ich przed obliczem Twoim ${ }^{9}$.

Diakon: Mądrość najwyźsza!

Lektor: Czytanie Listu świętego Pawła Apostoła do Efezjan.

Diakon: Bądźmy uwaźni!

Lektor: "Dziękujcie zawsze za wszystko Bogu 0jcu w Imię Pana naszego Jezusa Crrystusa. Bądźcie sobie wajemnie poddani w bojaźnt Chrystusowej. Żony niechaj będą poddane swym mężom jak Panu, bo mąż jest głowaz żony, jak 1 Chrystus - Głową Kościoła: On - Zbawca Ciała. Lecz jak Kościół poddany jest Chrystusowi, tak 1 źony mężom - we wszystkim. Mężowie miłujcie żony, bo

8 W Codex Barberini gr. 336 koronowanie odbywa się wilczeniu, a po koronowantu kapłan łazczy prawe dłonie nowozeńców. W Euchologionie Koalen /z $1027 \mathrm{r} . /$ koronowaniu towarzyszy obecna formuła ołogosławieństwa. W starożytności stosowano wieńce $z$ kwiatów $i$ nazwa obrzęu do dzisiaj znaczy dosłownie "wieńczenie". Obecnie natomiast używane saz metalowe korony.

9 Nie występuje w Codex Barberini gr. 336. Są to teksty Ps 20,4 17. 
1 Chrystus umiłował Kościóx i wydał za niego samego siebie, aby go uświęcić, oczýściwszy obmycien wodą, któremu towarzyszy słowo, aby osobiście stawić przed sobą Kościół jako chralebny, nie mający skazy czy zmarszczki, czy czegoś podobnego, lecz aby był święty i niesikalany. Mężowie powinni miłować swoje żony, tak jak własne ciało. Kto miłuje swoja żonę, siebie samego miłuje. Przeciez nigdy nikt nie odnosiz się z nienawiścia do wasnego ciała, lecz każdy je żywi 1 pielegnuje, Jak 1 Chrystus - Kościół, bo jesteśmy członkami Jego Ciała. Dlatego opuści człowiek ojca i matke, a połączy sie z żona swoja i bęa dwoje jednym ciałem. Tajemnica to wielka, a ja mówię: w odniesieniu do Chrystusa 1 do Kościoła. Tońcu więc niechaj także każdy z was tak miłuje swa źone jak siebie samego. A zona niechaj sie odnosi z czcia do swojego męża" /Ef $5,20-33 / 10$.

Chór: Alleluja, alleluja, alleluja.

Lektor: Ty, Pante, strzez nas i zachowaj /Ps 12,8/.

Chór: Alleluja, alleluja, alleluja.

Diakon: Mądrość najwyższa! Powstańmy! Usłyszymy świętą Ewangelię!

Kapłan: Pokój rszystkim.

Chór: I z duchem twoim.

Kapłan: Czytanie śriętej Ewangeli1 według Jana.

Chór: Chwała Tobie, Panie, chwała Tobie.

Diakon: Bądźmy uważni!

Kapłan: "W owym czasie /B.T.: Trzeciego dnia/ odbywało sie wesele w Kanie Galilejskiej i była tam Matka Jezusa. Zaproszono na to wesele takze Jezusa $i$ jego uczniów. A kiedy zabrakło wina, Matka Jezusa mówi do Niego: "Nie maja juź wina". Jezus jej odpowiedział: "Czyz to moja lub Twoja sprawa, Niewiasto? Czyz jeszcze nie nadeszła godzina moja?" Wtedy Matka jego powiedziała do sług: "Zróbcie wszystko, cokolwiek wam powie". Stało zaś tam sześć stągwi kamiennych przeznaczonych do żydowskich oczyszczeń, z których kaźda mogła pomieścić dwie lub trzy miary. Rzekł do nich Jezus: "Napełnijcie stągwie 
woda". I napełnili je az po brzegi. Potem do nich powiedział: "Zaczerpnijcie teraz 1 zanieście staroście weselnemu". Oni zaś zanieśli. A gdy starosta weselny skosztował wody, która stała się winem - nie wiedzlał bowiem, skąd ono pochodzi, ale słudzy, którzy czerpali wodę, wiedzieli - przywołał pana młodego i powiedział do niego: "Każdy człowiek stawia najpierw dobre wino, a gdy sį̨ napiją, wówczas gorsze. Ty zachowałeś dobre wino aź do tej pory". Taki to początek znaków uczyniz Jezus w Kanie Galilejskiej. Objawiz swoja chwałe 1 uwierzyli wiego Jego uczniowie" $/ J 2.1-11 /{ }^{11}$.

Chór: Chwała Tobie, Panie, chwała Tobie.

Diakon: Wołajmy wszyscy z całej duszy.

Chór: Kyrie eleison.

Diakon: Panie Wszechwładny, Boze 0jców naszych.

Chór: Kyrie eleison.

Diakon: Zmiłuj się nad nami, Boże, według wielkiego miłosierdzia Twego.

Chór: Kyrie eleison/trzy razy/.

Diakon: Módlmy się jeszcze o miłosierdzie, źycie, pokój, zdrowie, zbawienie 1 nawiedzente sług Bozych $N$. I N.

Chór: Kyrie eleison/trzy razy/.

Kapłan: Ponieważ jestés Bogiem miłosiernym 1 łaskawym, oddajemy chwałe Tobie, Ojcu 1 Synowi i Swiętemu Duchowi, teraz 1 zawsze i na wieki wieków.

Chór: Amen.

Diakon: Módlmy sį do Pana.

Chór: Kyrie eleison.

11 Również ewange11a nie wystę̧uje w Codex Barberini gr. 336. Bezpośrednio po koronowan1u następowała modlitwa pochylenia głów i udzielenie komuni /później "modlitwa wspólnego kieli-

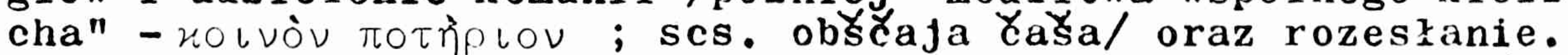
Udzielenie komuni bezpośrednio po wezwaniu "Uprzednio poświęcone święte dla świętycin" występuje jeszcze w Euchologionie Koalen /z $1027 \mathrm{r} . /$. Wspólny kielich z czerwonym winem nawiązuje do cudu w Kanie Galilejskiej. 
Kapłan: Panie Boże nasz, który w swojej zbawczej szczodrobliwości raczyłeś swoją obecnością Kanie Galilejskiej zaświadczyć, że małzeństwo jest godne czci, zachowaj $i$ teraz w pokoju 1 zgodzle sługi Twoje N. N., których zechciałeś połączyć wzajemnie ze sobą, okaż, że ich małżeństwo jest godne czci, zachowaj ich łoże nieskalane, zezwól by 1 ch wspólne źycie pozostało bez zmazy i spraw, aby osiagnęli starośc sędziwa, wypełniajac czystym sercem Twoje przykazania. Ty bowiem jesteś Bogiem naszym, Bogiem, który miłuje 1 zbawia $i$ oddajemy chwałe Toble z przedwiecznym Twoim 0jcem 1 Najświętszym, Dobrym $i$ życiodajnym Twoim Duchem, teraz $i$ zawsze 1 na wiek1 wieków.

Chór: Amen.

Diakon: Wspomóz, zbaw, zmiłuj się i zachowaj nas, Boże, swoją łaską. Chór: Kyrie eleison.

Diakon: 0 cały ten dzień, aby był doskonały, swiety, spokojny

1 bez grzechu, prośmy Pana.

Chór: Daj nam, o Panie.

Diakon: 0 Anioła pokoju, wiernego przewodnika, stróźa dusz 1 ciał naszych, prośmy Pana.

Chór: Daj nam, o Panie.

Diakon: 0 przebaczente 1 odpuszczente grzechów 1 przewinteń naszych, prośmy Pana.

Chór: Daj nam, o Panie.

Diakon: 0 to, co dobre 1 poźyteczne dla naszych dusz 1 o poḱj dla śviata, prośmy Pana.

Chór: Daj nam, o Panie.

Diakon: 0 to, byśmy resztę życia naszego spędzili w pokoju 1 pokucie, prośmy Pana.

Chór: Daj nam, c Panie.

Diakon: 0 chrześcijański koniec źycia naszego, bezbolesny, nieskalany, spokojny 1 o dobre usprawiedliwienie na strasznym sadzie Chrystusa, prosmy Pana.

Chór: Daj nam, o Panie.

Diakon: Zjednoczenie wierze 1 uczestnictwo Swiętego Ducha uprosiwszy, oddajmy samych siebie, Innych ludzi i całe zycie nasze Chrystusowi Bogu.

Chór: Tobie, o Panie. 
Kapłan: I pozwól nam, Władco, abyśmy mieli odwage z ufnością 1 bezkarnie wzywać Cieble, Niebieskiego ojca, i mówić:

Lud odmawia liodlitwe Pańską: "ojcze nasz, który jesteś w niebie..."

Kapłan: Twoje bowiem jest królestwo, moc i chwała, ojca i Syna

i Ducha Swiętego, teraz 1 zawsze 1 na wieki wieków.

Chór: Amen.

Kapłan: Pokój wszystkim.

Chór: I z duchem Twoim.

Diakon: Pochylcie głowy wasz przed Panem.

Chór: Przed Tobą, Panie.

Przynosi następnie wspólny k1el1ch, który kapłan błogosławi oraz odmawia modlitwe:

Diakon: Módlmy się do Pana.

Chór: Kyrie eleison.

Kapłan: Boze, Ty swoją mocą stworzyłeś wszystko, umocniłes okrąg ziemi 1 upiększyłeś wieniec wszystkiego, co nam stworzyłeś, pobłogosław błogosławieństwem duchowym ten wspólny kielich, który podajesz łączącym się we wspólnotę małźeńską. Błogosławione bowiem jest Twoje Imię 1 wysławiane jest̂ Twoje królestwo, ojca 1 Syna $i$ Swiętego Ducha, teraz 1 zawsze 1 na wieki wieków.

\section{Chór: Amen.}

Kapłan bierze w rece wspólny lielich 1 daje im trzykrotnie pić/pobłogosławione wino/, najplerw męzczyźnie, a potem kobiecie. Następnie oprowadza ich trzykrotni- w formie kręgu przy śpiewie kapłana lub ludu wykonujących następujące tropariony:

Ton 5: Wesel się, Izajaszu, oto Dziewica poczęła w łonie 1 zrodziła Syna Emanuela, Boga i Człowieka, a Wschód imię Jego, którego wielbiąc równiez samą Dziewicę nazywamy błogosławioną ${ }^{12}$.

Ton 7: Ślęci męczennicy, mężnie walczący 1 ukoronowani, módlcie się do Pana, aby zmiłował sie nad naszymi duszami ${ }^{13}$.

Ton 7: Chwała Tobie, Chryste Boże, chwała Apostołów, radości męczenników, którzy głosil1 Trójcę Współistotną ${ }^{14}$.

12 Irmos 9 od kanonu 5 tonu Oktoicha do słów Iz 7,14 i Za 6,12. Oprowadzanie wkoło jest symbolem wieczności. Występuje w obrzędach chrztu, małżeństwa oraz święceń diakonatu i kapłaństwa.

13 Troparion 7 tonu.

14 Troparion 7 tonu. Spiew trzech troparionów, w zmientonej kolejnośc1, towarzyszy tez św 1 ęceniom diakonatu 1 kapłaństwa. 
Kapłan zdejmuje koronę $z$ głowy oblubieńca mówiąc:

Bądź vywyższony oblubieńcze, jak Abrahari, błogosławiony jak Izaak i płodny jak Jakub, cnodzac w pokoju 1 rypełniając

w sprawiedliwości przykazania Boże.

Nastepnie zdejmuje koronę z głowy oblubienicy i mówi:

I ty, oblubienico, bądź wywyższona jak Sara, radosna jak Rebeka i płodna jak hachela, radując się ze swego męża

i zachowując granice Prawa, tak bowiem chcial Bóg.

Diakon: Módlmy sie do Pana.

Chór: Kyrie eleison.

Kapłan: Boże, Boże nasz, który przyszedłeś do Kany Galilejskiej,

1 pobłogosławiłeś tam celebrowane maxżeństwo, pobłogosław

i tym sługom Twoim, ltórzy z Twojej opatrzności połaczyli się we wspólnotę małzeńską. Pobłogosław ich wejścia 1 wyjścia, napełnif dobrami ich zycie, przyjmif ich korony czyste 1 nieskalane w Twoim Królestwie i zachowaj ich od wszelkich zasadzek na wieki wieków.

Chór: Amen.

Kapłan: Pokój wszystkim.

Chór: I z duchem Troim.

Diakon: Pochylcie głowy wasze przed Panem.

Chór: Przed Tobá, Panie.

Kapłan: Niech nas błogosławi 0jciec, Syn i Śrięty Duch, najwyższa, Współistotna 1 Życiodajna Trójca, mająca jedno bóstwo 1 królestwo, 1 niech was obdarzy diugowiecznością, licznym potomstwen, pełniz źycia i wiary i niech was napełni wszelkim1 dobrami ná ziemi i uczyni was godnymi przyjęcia obiecanych dóbr za wstawiennictwem najświętszej Bogurodzicy i rszystkich świętych.

Chór: Amen.

Wchodzą ${ }^{15}$ takze/rodzice/ 1 pozdrawiają nowożeńców, którzy całuja sie, a kapłan wygłasza "pełne rozesłanie":

15 Uzyte tu greckie słowo $\varepsilon l \sigma \varepsilon \rho \chi o \nu \tau \alpha \iota / s c s$. vchodjat/ oznacza starożytny obyczaj, zgodnie z którym rodzice nie uczestniczyli coremonil małzeńskiej swych dzieci, a sam ślub miał miejsce za barierką, przed królewskł bramą ikonostasu, gdzie poza narzeczonymi byli obecni tylko świadkowie. Po skończonej ceremonil rodzi- 
Diakon: Mądrość najwyższa!

Chór: Unielbłamy Cię, Bogurodzico, czcigodniejsza od Cherubinów 1 niezrómnanie sławniejsza od Serafinów, któraś w dziewictwie zrodziła Słowo Boga.

Kapłan: Chwała Tobie, Chryste Boże, Nadziejo nasza, chwała Tobie. Chór: Chwała 0jcu I Synowi 1 Swiętemu Duchowi, teraz 1 zawsze 1 na wieki wiekóm. Amen. Kyrie eleison /trzy razy/.

Kapłan: Chrystus, praødziny Bóg nasz, który przez swoje przyjście do Kany Galllejskiej uznał małzeństwo za godne czci, przez wstamiennictwo Swojej niepokalanej Matki, świętych, chwalebnych 1 w całym świecie sławnych Apostołów, f́więtych przez Boga ukoronowanych 1 równych Apostołom cesarzy Konstantyna i Heleny, świętego wielkiego męczennika Prokopa 1 wszystkich świętych, niechaj sį̨ zmiłuje 1 zbawi nas.

Chór: Amen.

Modlitwa na zdjęcie koron, odmawiana ósmego dn1a /po ślubie/ ${ }^{16}$ :

Kapłan: Panfe Boze nasz, który błogosławiłeś wieńcowi roku 1 poleciłeś nakładać te wieńce łączącym się wzajemnie małżeńskim prawem dając im niejako nagrodę za wstrzemieźliwość, pon1eważ czyści pospieszyli do uśrięconego przez Ciebie małzeństwa, sam teraz pobłogosław zawierającym ze sobą ten związek małżeński przy zdejmowaniu wieńców, zachowaj ich małżeństwo nierozerwal nym, aby we wszystkim dziękowali najśmiętszemu Imieniu Twojemu, Ojca 1 Syna 1 Świętego Ducha, teraz 1 zansze 1 na wieki wieków.

Chór: Amen.

Kapłan: Pokój wszystkim.

Chór: I z duchem twoim.

Diakon: Pochylcie głowy wasze przed Panem.

ce mchodzili za barierke, składali źyczenia swym dzieciom, całowal1 je i zmuszali do pocałowania się. Kapłan nie brał udziału Tej ceremonil /porównaj S.Bulgakov, Nastolnaja kinga dla sviǎ̧̌enno-cerkovno-služitelej, Graz $1977^{3}, 1157$, nota 33 .

16 Tekst: Goar 325. 
Chór: Przed Tobaz, Pante.

Kapłan: Panie, my, słudzy Two1, potwierdziwszy zgodne umowy, spełniwszy obrzęd zaślubin na wzór owych Kante Galilejskiej 1 zamknąwszy zwiazzane z nimi symbole $e^{17}$, chwałe Ci oddajemy, 0jcu 1 Synowi $i$ Swietemu Duchori, teraz 1 zawsze 1 na wieki wieków ${ }^{18}$.

Chór: Amen.

tłum. ks. Henryk Paprocki - Farszawa

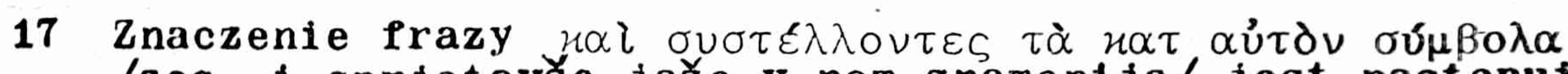

/scs. 1 sprjatavše jaže $v$ nem znamenija/ jest nastepujące: rodzice narzeczonych zawierali umowę w sprawie posagu, w obecności śriadków, a po zawarciu małźeństwa przekazywali wszelkie dokumenty 1 notatki z tym zwiazzane nowoźeńcom, którzy je chowall /S.Bulgakov, Nastulnaja kniga, dz.cyt., 1158, nota 40/.

18 Modlitwa ta występuje w Codex Porfirii/X wiek/. W staroźtności nowoźeńcy nosili wieńce splecione $z$ roślin w ciagu ośmiu dnt po zawarciu ślubu. 